によりもとめ,いずれかが $5 \%$ 以下の危険率で有意差 を認めたものを正規分布していないと判定した。また， 実測値を対数変換した值についても正規性を検討し た。

正規性の検定結果加占，P III，P V，N III，N V 波 およびII波面積では，対数值よりも実測值のままで正 規分布しており，正規分布していなかったのは16部位 中 3 個以内であった。また，IV-V波面積は両耳刺激 を除いて夷測值で正規分布しなかった部位は 2 個以内
であった，CV の検討から，P III，P V，N III，N V波 のCVはそれぞれの base-peak 法で測定した振幅と ほほ同程度で，III，IV-V波面積の CV はそれそれ peak-peak 法で測定したIII，V波振幅と同程度であっ た。以上, 正常者 $\mathrm{ABR}$ の速波成分に扔ける波形面積の 統計的性質の検討から，面積の測定方法にはさらに検 討が必要であるが，P III，P V，N III，N V 波および III, IV－V波面積はSPM の指標となりうると考えら れた。

\title{
384。椎骨脳底動脈系の虚血状態における $\mathrm{ABR}$
}

\author{
布施健生・青柳 儤・鈴木 豊・小池吉郎（山形大）
}

目的 ABRは音刺激により誘発される反応であ り，各波の起源が中枢聴覚路にあると考えられ脳幹機 能を把握するのに有用である、しかし，椎骨脳底動脈 系の虚血状態における ABR 所見の変化に関する報告 は少ない。本研究の目的は, 椎骨脳底動脈系の変動す る虚血状態に抢ける $\mathrm{ABR}$ 変化を検討することであ る.さらに, 聴覚路における虚血の程度と ABR 変化の 関連を調べることである。

症例と方法 臨床例は，頸部を捻転した際に左椎骨 動脈が kinking を起こす 1 例において, kinkingを起 こす状態で経時的な ABR を測定した。手術中に椎骨 動脈を遮断操作した 1 例は, 椎骨動脈遮断後の ABR を測定した。以上の2 例を呈示し，椎骨脳底動脈系の 変動する虚血状態に斿けるABR変化を検討した。一 方, 聴賞路における虚血の程度とABR 変化の関連を 調べる際には動物実験を施行した。実験はモルモット を用い，両側の総頸動脈と一側または両側の椎骨動脈 を遮断し脳虚血モデルを作成した。脳虚血モデルにお ける経時的な ABR 変化とレーザードップラー血流計 に上る蝸牛の血流量老測定し, ABR 変化に対する蟜
牛血流量を検討した。

結果 1) ABR は椎骨脳底動脈系の虚血に敏感で ある，2）椎骨脳底動脈系の虚血状態に扔ける ABR 所見の変化として, 各波の振幅の低下とV波潜時の延 長が譛められた，3）虚血状態により ABR 上高度の V波延長または無反応が認められても，血流の改善に より ABR 所見は回復する.4）蝸牛血流量の減少に ともない，ABRの潜時延長と振幅の低下がすすんだ.

5）虚血の進行により $\mathrm{ABR}$ が無反応となった時点で も，ある程度の蝸牛血流量が認められた，4）・5は動 物実験による結果であり，七トとは脳虚血状態や ABR 起源が異なるが，ヒトに扔ける聴覚路の虚血程 度とABR 変化の関連を示唆するものと考えた。 質問 佐藤信清(北大). 1) 蝸牛血流量と ABR 無反 応の関連について. 2) 血流遮断の時間, 程度と $A B R$ の可逆性, 不可逆性について。応答 1) 1984年 のSohmer らも述べているが, ABR 無反応時でもcochlear blood flow は残っていると思われる.2） ABR の可逆性については，検討していない。

\section{5．前下小脳動脈系循環障害と $\mathrm{ABR}$}

\section{姜 学鈞・伊藤久子（浜松医大）}

脳底動脈より内耳動脈にいたる前下小脳動脈系に閉 塞を加えたときに生ずる $\mathrm{ABR}$ 及び蝸牛血流の変化に ついて検討した。

方法 実験動物にネンプタール麻酔したネコを用い た. ABR の誘発記録には Neuropack-II (日本光電製) を使用し外耳道に㨀入したイヤホン $(\mathrm{YE}-101 \mathrm{~J})$ より 刺激音を与えた。刺激音压は $60-90 \mathrm{dBnHL}$, 加算は 16 -128 回で $\mathrm{S} / \mathrm{N}$ 比良好な限りなるべく小さく各動物毎 に設定し，非検側耳には刺激音より $40 \mathrm{dBnHL}$ 小さい masking 音を与えた。蝸牛血流の測定は蝸牛基底回転 骨壁を削った上にプローベを置きレーザー血流計

\begin{tabular}{|c|c|c|c|}
\hline & $\begin{array}{l}\text { 内耳 } \\
\text { 動脈 }\end{array}$ & $\begin{array}{l}\text { 前下小 } \\
\text { 脳動脈 }\end{array}$ & $\begin{array}{l}\text { 脳底 } \\
\text { 動脈 }\end{array}$ \\
\hline $\mathrm{ABR}$ 無変化 & 10 & 15 & 9 \\
\hline I 波潜時延長～消失 & 2 & 1 & 0 \\
\hline I . II .波潜時延長〜消失 & 8 & 2 & $(1)^{*}$ \\
\hline I . II . III 波潜時延長〜消失 & 3 & 0 & 0 \\
\hline I . II . III.NN波潜時延長〜消失 & 8 & 1 & 0 \\
\hline III. N 波潜時延長～消失 & 0 & 3 & 2 \\
\hline
\end{tabular}


(ALF2100)によった. 実験中は $38^{\circ} \mathrm{C}$ 前後に直腸温を保 ち, pancronium で筋弛緩し調節呼吸とした。

結果 動脈閉塞部位別の $\mathrm{ABR}$ 変化は以下の通りで あった(表)。蝙牛血流の低下度は末梢に閉塞がある活 ど大きい傾向にあった，I．II波は螖牛血流が低下し たものほど潜時延長，振幅低下をきたしやすい傾向が
みられた。

まとめ1. 閉塞部位が末梢にあるほど蝸牛血流が 低下し易い．2，蝸牛血流の低下はI．II 波の変化と 相関する．3．中枢側に閉塞があるとき，ABR 变化が あるとす机ばIII波以後にみられ易いが，螖牛血流の低 下を伴ってI，II波にも見られる例がある。

\title{
386。新生児乳児の MLR
}

\author{
植田広海・柳田則之（名大）
}

今回我々は，新生児乳児を対象に, ABR 及び MLR を施行し，検討したので報告した。対象注，社会福祉 法人聖霊会聖霊病院 NICU に入院中及び退院後で, 受 胎後週数換算にて36週から44週までの新生児及び乳児 で,コントロール群として, 生下時体重 $2500 \mathrm{~g}$ 以下 $2000 \mathrm{~g}$ 以上の軽度の低出生体重児29耳, 異常群として, 仮死, 黄疸, 頭蓋内出血, 感染症にて聴器毒性抗生剂 使用歴ある等の難聴の可能性のある児 $170 耳$ 耳 2 群に 分類した. 方法は、被検児にトリクロリール $100 \mathrm{mg} / \mathrm{kg}$ 服用させ，Danac 9 を使用し，安静睡眠状態下に，防 音室にて測定した。刺激音は, ABR 測定時は, クリッ ク, MLR 測定時はクリックあるいは $500 \mathrm{~Hz} ト$ トンピ ップを使用した。各波の出現率の算定は, $55 \mathrm{dBnHL}$ 再現性のみられるものを陽性として計算した。域値の 指標として ABRではV波，MLRではPoNa 波を採 用した。クリック刺激では, コントロール, 異常群と も, ABR, MLR 域值間に, 有意の差を認めなかった。 よってMLRにおける $\mathrm{Po}, \mathrm{Na}$, Na2 波も, 自覚域值 推定の指標になりうると思われた。タリック刺激によ るABR と， $500 \mathrm{~Hz}$ トーンピップ刺激による MLR と の比較では, コントロール群, 異常群とも MLR 域值 は, $\mathrm{ABR}$ 域值よりもやや悪くなっていたが，その差は
平均で $10 \mathrm{~dB}$ 以下であった。この結果から，Po，Nal， $\mathrm{Na} 2$ は, 新生児乳児に㧍いて低周波域の自覚域值推定 の指標になりうるのではないかと思われた。 $55 \mathrm{dBnHL}$ のクリック刺激に上る ABR と MLR の潜時及び各波 の出現率を比較すると, コントロール群, 異常群との 間に有意の差を認めなかった。またP波は，ほとんど 認めず，Na2 波も認めない例が多く見的た。 $\mathrm{Pa}$ 波に 関しては, 両群共 $40 \%$ 台で出現がかなり不安定であっ た. $55 \mathrm{dBnHL}$ のクリック刺激によるABR及び $500 \mathrm{~Hz}$ トーンピップ刺激による MLRの潜時及び出 現率を比較すると, 同様にコントロール群及び異常群 との間に，潜時出現率に有意の差を認也なかった。た だ特徵的な点は，P， Na2 波はほほ100\%に見られたと いう点であった。一方，Pa 波の出現率は，クリック刺 激時よりさらに悪く，20\%台であった。よって，Pa 波 は聴賞系の異常の検出に現方法では有能ではないと思 われた。質問 木村謙一(福岡大). 特徴的な $\mathrm{P}$ 波 について新生児乳照に特徵的なのか. 音刺激の特徵か。 応答 症例数が成人では,少ないので断言出来ないが, クリック刺激では $\mathrm{P}$ 波り出現率は，新生児よりも高く なっているように思われる。その意昧については，上 くわからない.

\section{7. 内リンパ囊開放術前後の蝸電図変化}

\section{麻生 伸 - 長崎孝敏・渡辺行雄 - 水越鉄理（富山医薬大）}

目的浸透压利尿剤が薬物による内リンパ水腫の減 荷であるとすれば，外科的にこれを軽隇させる方法が 内リンパ露開放術といえる。内リンパ水腫の診断に蝸 電図の一SP增大現象の有用性が指摘されて久しい が，仮に蝸電図が内リンパ翼開放術によって変化する ならば, 手術効果の確認にも有用であり, 逆に内リン 八゚水腫が蜡電図異常の原因であるという論拠にもなる と考えた．今回はこれらの点を明らかにする目的で以 下の臨床例について検討を加えたので報告した。

方法当科で内リンパ靁外壁翻転法（北原）を施行 したメニエール病患者のうち, 術前後に判定可能な蝸 電図を記録し得た11例について比較検討した。蝸電図
は針電極を用いた岬角誘導である。また予後との関倸 をみるために AAOHNS 評価基準を参考にした。これれ には術後 2 年以上の経過観察を要する。

結果 1) 術後のSP/AP の変化を調べると, 術前 の值から $10 \%$ 以上減少した例が 5 例, 增大した例が 3 例, 不变例が 3 例であった。增大あるいは減少群に予 後良好例が多かった，2） SP/APが減少している5 例中 1 例はまだ 2 年間の経過観察期間中であるが, こ れを除いた10例中術後の経過が良好とはい之ないWC (Worse Control : 悪化) と IC (Insufficient Control : 無効）はともに1症例ずつあった。この2例とも術前 後のSP/AP が不変の症例であった。 